\title{
Does the landscape surrounding streams affect the occurrence of freshwater crabs? A case study of the genus Aegla (Crustacea: Decapoda: Anomura) in subtropical basins
}

\author{
Cassiano Estevan (D), Luiz U. Hepp (D), Vanderlei S. Decian (D) \& Rodrigo Fornel (1)
}

Programa de Pós-Graduação em Ecologia, Departamento de Ciências Biológicas, Universidade Regional Integrada do Alto Uruguai e das Missões (URI), Campus Erechim, Av. Sete de Setembro 1621, 99709-910 Erechim, RS, Brazil. (rodrigofornel@hotmail.com)

Received 10 January 2018

Accepted 27 April 2018

Published 21 June 2018

DOI: 10.1590/1678-4766e2018024

ABSTRACT. Changes in the landscape where watersheds are located may affect the stream biota in different ways. In order to explore this idea, we collected freshwater crabs of the genus Aegla Leach, 1820 in subtropical region of southern Brazil. We also measured a number of landscape features and physico-chemical variables in the collection streams and surroundings in order to ascertain which factors affect the occurrence of these crustaceans. A total of 167 individuals of Aegla were collected in 21 streams. The collection was comprised of three species: A. odebrechtii, A. platensis, and A. singularis. The occurrence of $A$. platensis was influenced by physico-chemical variables (total carbon and total organic carbon) and stream morphometry factors (level curves sum). The occurrence of $A$. singularis was influenced by land use (pasture and exposed soil and agriculture) and the stream morphometry (level curves sum). Only a small number of $A$. odebrechtii were collected and their occurrence was influenced by land use (pasture and exposed soil and agriculture). The topography of the area studied limits the types of land use and areas that are less favorable for agriculture (more hilly areas) are have more riparian vegetation (or less anthropic stress). As a result, these areas are less subject to changes in water quality, which is reflected in the distribution of Aegla species.

KEYWORDS: Limnological factors, stream morphometry, land-use, anthropization, agriculture.

RESUMEN. ¿EI paisaje que rodea los arroyos afecta la ocurrencia de los cangrejos de agua dulce? Estudio de caso del género Aegla (Crustacea: Decapoda: Anomura) en cuencas subtropicales. Los cambios en el paisaje donde se ubican las cuencas hidrográficas pueden afectar la corriente de diferentes maneras. Con el fin de explorar esta idea, se recogieron los cangrejos de agua dulce del género Aegla Leach, 1820 en la región subtropical del sur de Brasil. También se midió una serie de características del paisaje y las variables físico-químicas en los arroyos de colección y el entorno con el fin de determinar qué factores afectan la ocurrencia de estos crustáceos. Un total de 167 individuos de Aegla fueron recolectados en 21 arroyos. La colección estaba compuesta por tres especies: $A$. odebrechtii, $A$. platensis y $A$. singularis. La ocurrencia de $A$. platensis estuvo influenciada por variables fisicoquímicas (carbono total y carbono orgánico total) y morfometría (suma de curvas de nivel). La ocurrencia de $A$. singularis estuvo influenciada por el uso de la tierra (pastos y suelo expuesto y agricultura) y la morfometría (suma de curvas de nivel). Sólo un pequeño número de $A$. odebrechtii fueron recolectados y su ocurrencia fue influenciada por el uso de la tierra (pastos y suelo expuesto y la agricultura). La topografía del área estudiada limita los tipos de uso de la tierra y las áreas menos favorables para la agricultura (zonas más montañosas) tienen más vegetación ribereña (o menos estrés antrópico). Como resultado, estas áreas están menos sujetas a cambios en la calidad del agua, lo que se refleja en la distribución de las especies de Aegla.

PALABRAS CLAVE. Factores limnológicos, morfometría de arroyos, uso de la tierra, antropización, agricultura.

The maintenance of diversity and the function of aquatic ecosystems are closely associated with habitat conservation, the environment, and the maintenance of natural energy flow regimes (POFF et al., 1997; ElOSEGI \& SABATER, 2013). Aquatic environments reflect the land uses that occur in their drainage areas (SENSOLO et al., 2012), and thereby become vulnerable to environmental degradation (VÖRÖSMARTY et al., 2010; WoODWARD et al., 2012). Thus, the quality of these environments is related to anthropogenic practices developed in their watersheds (NGOYE \& MACHIWA, 2004; Foley et al., 2005; Bu et al., 2014; KNYSH, et al., 2016). Urbanization, agriculture and industrial activities generate changes in the physical, chemical, and biological characteristics of aquatic environments through the removal of riparian vegetation and the input of nutrients, organic matter, pesticides, and heavy metals (KANG et al., 2010; SouZA et al., 2013; THEODOROPOULOS et al., 2015; KNYSH et al., 2016).

Studying the morphometry characteristics of a river basin, along with land use in the area, can aid in assessing the possible effects of disturbances in the ecosystem and identifying the areas of greatest weakness for anthropization (Oliveira et al., 2008; Olszevski et al., 2011). Hydrogeomorphologic or morphometry factors that related to environmental vulnerability include features such as drainage density, roundness index, and average steepness. These 
factors can encourage human activities in the catchment area intensifying erosion and interfering with the dynamics of surface water resources (OLIVEIRA et al., 2008; SANTOS \& SOBREIRA, 2008). These morphometric characteristics may also be associated with the occurrence and distribution of aquatic organisms (RIBEIRO \& SALOMÃo, 2003).

Studies have found that various aquatic organisms respond differently to changes in land use (SENSOLO et al., 2012; De Toni et al., 2014; FerReIRA et al., 2014; TeresA et al., 2015; RiBeiro et al., 2016). However, studies on the effects of such changes in land use and the landscape morphometry of drainage areas on crustaceans are still incipient. Some studies on the conservation of the South American freshwater crayfish [Parastacus pugnax (Poeppig, 1835)] have revealed that this crustacean responds negatively to pollution resulting from urbanization, industrialization, agricultural practices, and siltation linked to deforestation (BuCKuP, 2010; Almerão et al., 2015). TREVISAN et al. (2009) found that for some species of Aegla Leach, 1820 shows sensitivity to changes in land uses, and these species change their occurrence as a function of human occupation of the drainage area of streams. Corroborating this statement, Dalosto \& SANTOS (2011) have also recorded the sensitivity of decapods to land use, observing declining populations in response to the presence of pesticides in river basins.

The southern of Brazil presents an expressive area used by agriculture (DECIAN et al., 2009) and these activities fragments the environments damaging the aquatic biota (НЕPP et al., 2010), we carry out this study with species of Aegla. Crabs of genus Aegla are endemic to southern South America, occurring in the river basins of southern Brazil, Uruguay, Argentina, southern Bolivia, Paraguay, and south-central Chile (GonÇALVES et al., 2006). The genus has 83 extant species that usually have very limited distributions (SANTOS et al., 2017). This factor, combined with rapid environmental degradation of aquatic environments, makes these crustaceans a source of significant concern for conservation with almost $70 \%$ of species under some level of threat (MARCHIORI et al., 2014; SANTOS et al., 2017; Crivellaro et al., 2018). Thus, in this study, we assess the occurrence of Aegla species in streams located in the southern Brazil. The main question of this work was: does the landscape surrounding streams affect the occurrence of freshwater crabs? In addition, we evaluated the variation of limnological variables, stream morphometry characteristics, and land cover in drainage watersheds of streams and their effects on the occurrence of aeglids. We expect that the influence of land use in the drainage basins of the streams is regulatory factor of the occurrence of aeglids.

\section{MATERIAL AND METHODS}

Study area. The study was conducted in southern Brazil, in streams located in the upper portion of the Uruguay River basin $\left(27^{\circ} 12^{\prime} 59^{\prime \prime} \mathrm{S}, 52^{\circ} 48^{\prime} 12^{\prime \prime} \mathrm{W}\right.$ and $28^{\circ} 00^{\prime} 47^{\prime \prime} \mathrm{S}$, $51^{\circ} 49^{\prime} 34^{\prime \prime}$, Fig. 1). The altitude varies between $270-800$ $\mathrm{m}$ (a.s.l.), with an average annual temperature of $17.6^{\circ} \mathrm{C}$ and average precipitation of $1912 \mathrm{~mm}$ (BERNARDI \& BUDKE, 2010). The climate is subtropical type $\mathrm{Cfb}$ of Köppen (Alvares et al., 2013). The region is part of the Atlantic Forest Domain and the vegetation consists of a mixture of subtropical forest and mixed rain forest (OliveIRA-FiLho et al., 2015). With less than $10 \%$ of its original coverage, the Atlantic Forest is considered one of the hotspots for conservation priorities (MYERs et al., 2000). The landscape presents diversified land use, with strong anthropic pressure. About $75 \%$ of the area is used for agriculture and there is a low percentage of forest remaining $(<20 \%)$ (DECIAN $e t$ al., 2009).

Collection of Aegla. We captured specimens in 21 streams $\left(\leq 4^{\mathrm{a}}\right.$ order) not connected distributed throughout the study area (Fig. 1). Specimens were collected with the use of a hand net $(0.5 \mathrm{~mm}$ mesh) for about 30 minutes per stream in a stretch of water about $40 \mathrm{~m}$ long. The different types of substrates founds (e.g. stones, leaves, twigs, marginal aquatic vegetation) were also collected from each location. We adopted this method to try to understand all the possible habitats of these organisms. We fixed the individuals caught with $70 \%$ alcohol and identified the species according to BOND-BUCKUP \& BuCKUP (1994). After identification, specimens were listed in the collection of Museu Regional do Alto Uruguai - URI Erechim.

Physico-chemical and landscape variables. According to previous studies, the general anthropic activities observed in the study region (eg agriculture and urbanization) have a significant contribution of organic matter, nutrients and metals (Hepp \& Santos, 2009; Hepp et al., 2010; Sensolo et al., 2012). In this way, we chose to quantify the electrical conductivity, total nitrogen, total carbon, organic carbon, and inorganic carbon variables and use them as limnological descriptors. Thus, we collected water samples for quantification of varying electrical conductivity (Condutivitymeter brand Marconi, model MA-521), total nitrogen, total carbon, organic carbon, and inorganic carbon (Analyser TOC Shimadzu ${ }^{\circledR}$ ). Our collection and analysis procedures followed the methods described in Standard Methods (APHA, 1998).

We used images of digital dataset, from the LANDSAT TM Platform 8, from the INPE (Instituto Nacional de Pesquisas Espaciais), dated September 18, 2015. Digital processing of satellite images was performed in order to improve the enhancement of color, brightness and contrast to analyze the patterns of land use and occupation. For the georeferencing of satellite images, coordinates were collected (SIRGAS 2000 UTM coordinate system and 22S spindle, with a final presentation scale of 1: 50,000). Afterwards, the digital classification module supervised by the Maximum Likelihood method (MaxVer) of the IDRISI ANDES Application was applied. Kappa index and terrestrial truth were applied to ascertain the sampling patterns (obtaining an optimal index, greater than 94\%).

The categorization of land use and land cover was adapted from the systematic classification of the Land 


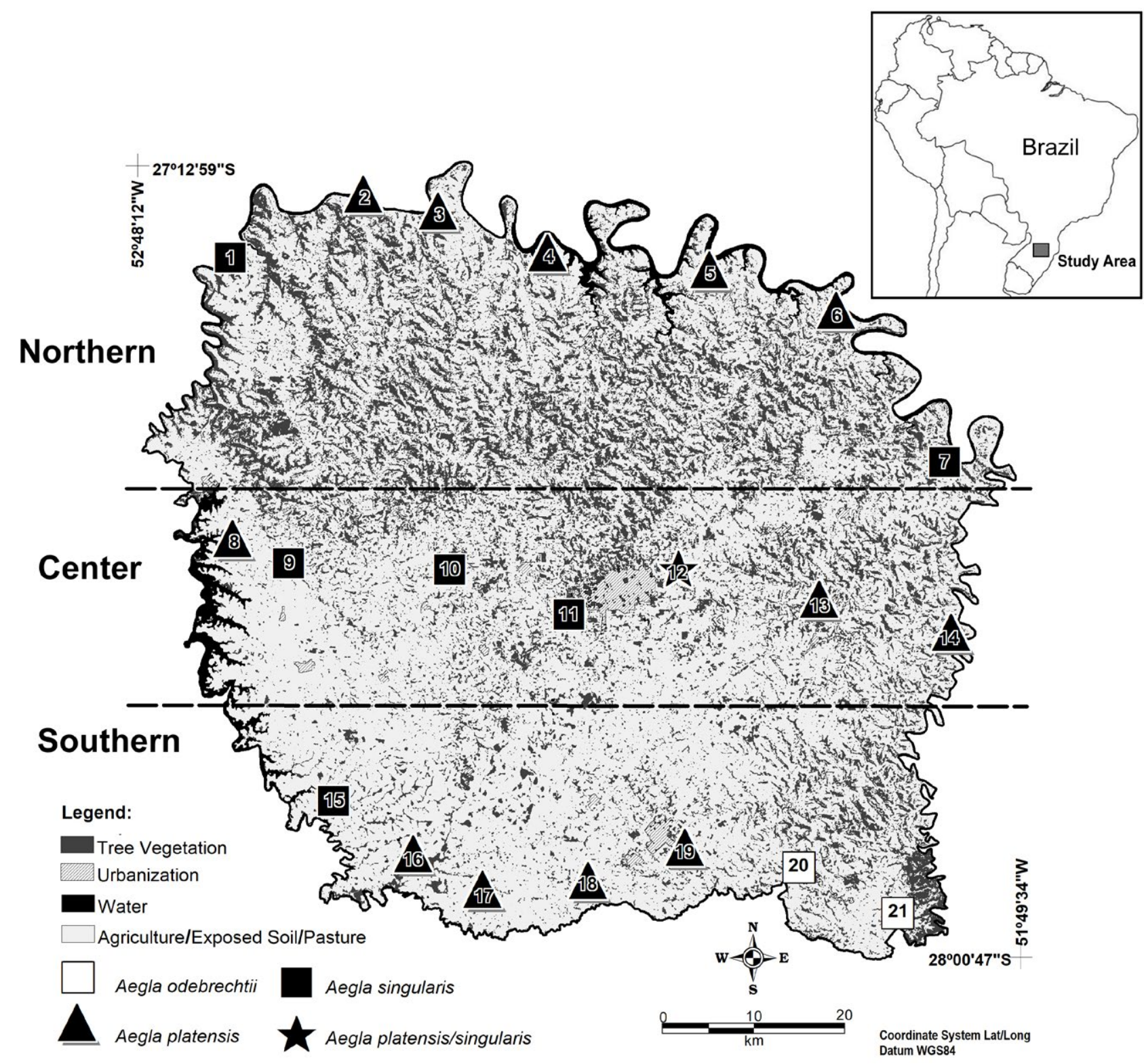

Fig. 1. Map of the study area in state of Rio Grande do Sul, southern Brazil showing land uses and the location of sampling sites (1 through 21$)$ in the northern, central and southern regions.

Used Technical Manual, proposed by Instituto Brasileiro de Geografia e Estatística. We quantified stream morphometry variables following the methods of CHRISTOFOLETTI (1980) and MACHADO et al. (2009). We measured the drainage area (A), perimeter $(\mathrm{P})$, drainage density (Dd), total length of the channels (CTC), circularity index (Ic), average slope $(\mathrm{Dm})$, rugosity coefficient $(\mathrm{RN})$, gradient of the main river $(\mathrm{G})$, the sum of level contours (SCN), and the length of the main channel (CCP). More details on these variables see Appendix 1.

Data analysis. To evaluate the differences between the environmental variables of the streams located in different parts of the study area, we used analysis of variance with an a posteriori Tukey test. Further, we use Pearson linear correlation between variables to determine the association between them, especially to explain the relationship between hydro-geomorphological structure and land uses.

To assess the effects of physico-chemical variables and landscape on the occurrence of crustaceans we began with a Principal Component Analysis (PCA) to summarize the variation generated by the variables measured in the stream morphometry (i), physico-chemical variables (ii), and land cover (iii) matrices. From the analyses, we extracted the scores of the first principal component of each PCA to constitute a new explanatory matrix containing a summary of stream morphometry information, physico-chemical variables and land cover. We used this procedure to eliminate linearity of variables and avoid distortions in the analysis. With this new explanatory matrix, we performed a Redundancy Analysis (RDA) to assess the effects of these variables on 
the occurrence of aeglid species in streams. To carry out the analysis we used the software R (R CORE TEAm, 2013) and functions of the 'vegan' package (OKSANEN et al., 2010).

\section{RESULTS}

Physico-chemical and landscape variables. Among all of the environmental variables studied (stream morphometry, land cover, and physico-chemical), only the declivity, total nitrogen in the water, exposed soil/ agriculture, and pastures showed variation among the three regions studied (Fig. 2; Appendix 1). The declivity of the streams was significantly different between the three regions studied $\left(F_{2,18}=6.64, P=0.007\right)$. The streams located in the northern region $(29.5 \pm 1.0 \%$; average $\pm \mathrm{SE})$ showed greater declivity that the streams in the south $(16.3 \pm 3.1 \%)$. The total nitrogen concentration of the water was highest in the central region $\left(1.58 \pm 0.22 \mathrm{mg} \mathrm{L}^{-1}\right)$ and lowest in the northern region $\left(0.45 \pm 0.05 \mathrm{mg} \mathrm{L}^{-1}\right)\left(F_{2,18}=11.4, P=0.0009\right)$. However, the total nitrogen concentrations were similar between the northern and southern regions (Fig. 2).

Land cover had greater variation than environmental variables. The percentage of exposed soil and implemented agricultural was significantly higher in the central and southern regions $(66.0 \pm 4.9 \%$ and $76.9 \pm 3.3 \%$, respectively) than in the northern region $(27.9 \pm 5.5 \%)\left(F_{2,18}=31.2, P<0.001\right)$.
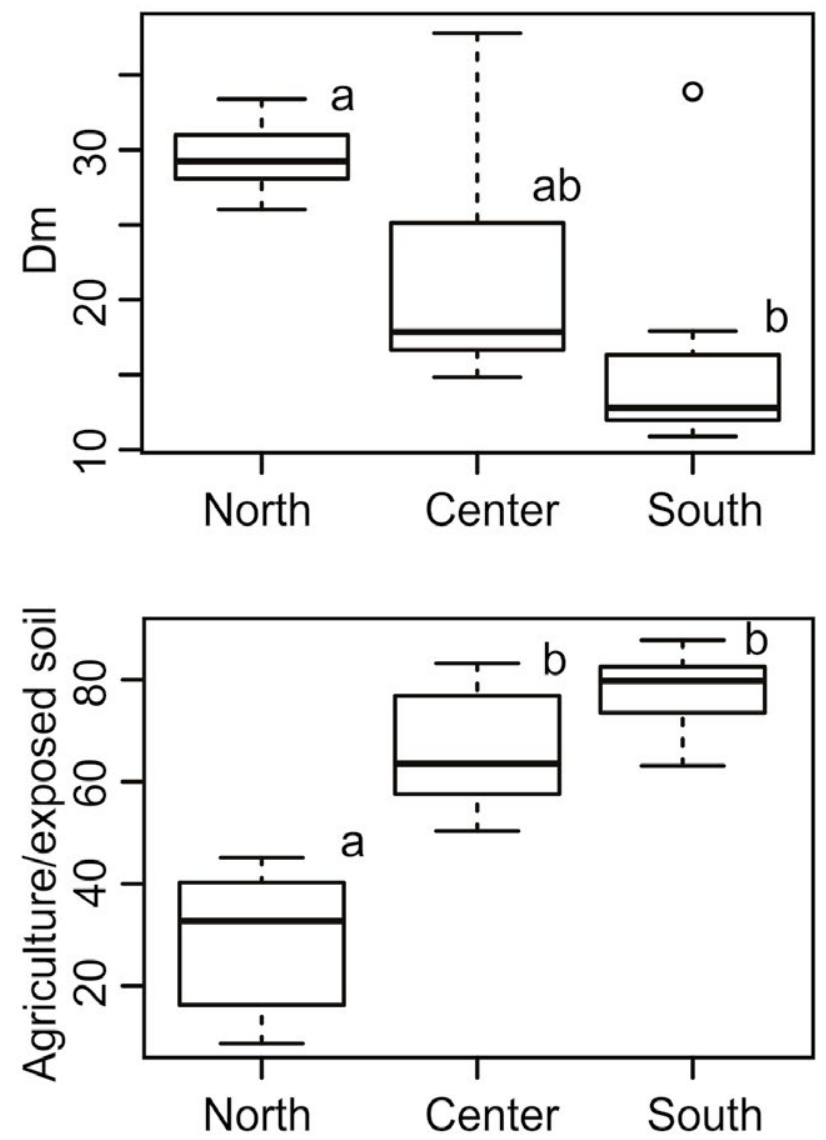

On the other hand, the amount of pasture was higher in the northern region $(54.8 \pm 7.8 \%)\left(F_{2,18}=27.1, P<0.001\right)$. The amount of pasture in the central and southern regions was similar (15.3 $\pm 3.1 \%$ and $7.2 \pm 0.7 \%$, respectively) (Fig. 2). Besides showing variations between regions, these variables also showed significant correlations between them.

Agricultural areas are more prevalent in streams drainage basins with a lower average slope $(r=-0.77, P<$ $0.001)$. Moreover, locations with the greatest slope have a higher percentage of pasture $(r=0.58, P=0.005)$. The total nitrogen concentration in the water was higher in streams surrounded by agriculture $(r=0.55, P=0.008)$ and lower in streams surrounded by grazing areas $(r=-0.56, P=0.007)$. Finally, the percentage of pasture was smaller in areas with intensive agriculture $(r=-0.94, P<0.001)$.

Occurence of Aegla. We collected 167 individuals of three species of Aegla: A. odebrechtii (Müller 1876), A. platensis (Schmitt 1942), and A. singularis (Ringuelet, 1948). The species occurred in isolation in 20 streams. Sympatry between $A$. plantensis and $A$. singularis was observed in only one stream (Fig. 1). Aegla platensis was the most frequent occurring species (61.9\% of streams), followed by $A$. singularis (33.3\%) and then A. odebrechtii (9.5\%).

PCA performed with the stream morphometry variables showed that the sum of level contours explained $99 \%$ of the total variation in this data set. For physico-chemical
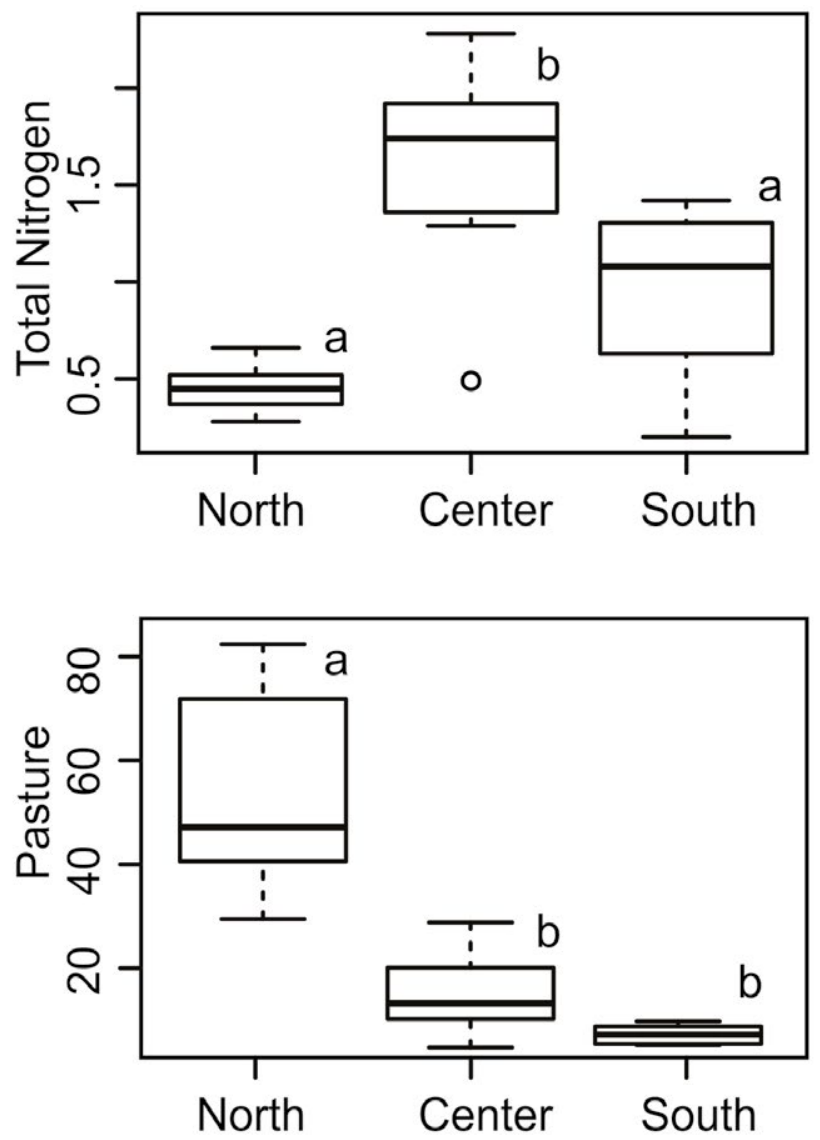

Fig. 2. Boxplot of limnological differences (total nitrogen), stream morphometry hydro-geomorphological differences (Dm) and land use differences (agriculture/exposed soil and pasture) in the three regions (northern, central, and southern) of the study area, state of Rio Grande do Sul, southern Brazil. Different letters above boxes represent significant differences among groups. 
variables, total carbon and total organic carbon explained $64 \%$ of the limnological variation in the streams. Finally, the pasture and exposed soil or agriculture land cover explained $35 \%$ of variation in the usage of the drainage areas of streams. As these were the variables that best summarized the data, they were used in the evaluation of the distribution of aeglids.

Aegla odebrechtii occurred only in the southern region of the study area (Fig. 1). The occurrence of A. platensis was influenced by the physico-chemical variables (total carbon and total organic carbon) and stream morphometry factors (the sum of level curves) (Fig. 3). On the other hand, the occurrence of $A$. singularis was influenced by land cover (pasture and exposed soil/agriculture) and stream morphometry of the landscape (Fig. 3). The limited occurrence of $A$. odebrechtii was influenced by land use (Fig. 3).

\section{DISCUSSION}

The landscape of the study region presents a clear pattern of land use distribution, considering the predominance of the anthropic activities observed in the area. In the northern region there is a predominance of pasture areas and arboreal vegetation, while in the south, the land is mainly used for agricultural activities. In the central region a transition zone with increased urbanization, we observed higher concentrations of nitrogen dissolved in the water. Urban activity negatively contributed to the quality of the aquatic environments, since waste is released into water bodies without treatment (HEPP et al., 2010). The release of high amounts of nutrients, nitrogen and phosphorus, in streams cause eutrophication in these environments. Eutrophic

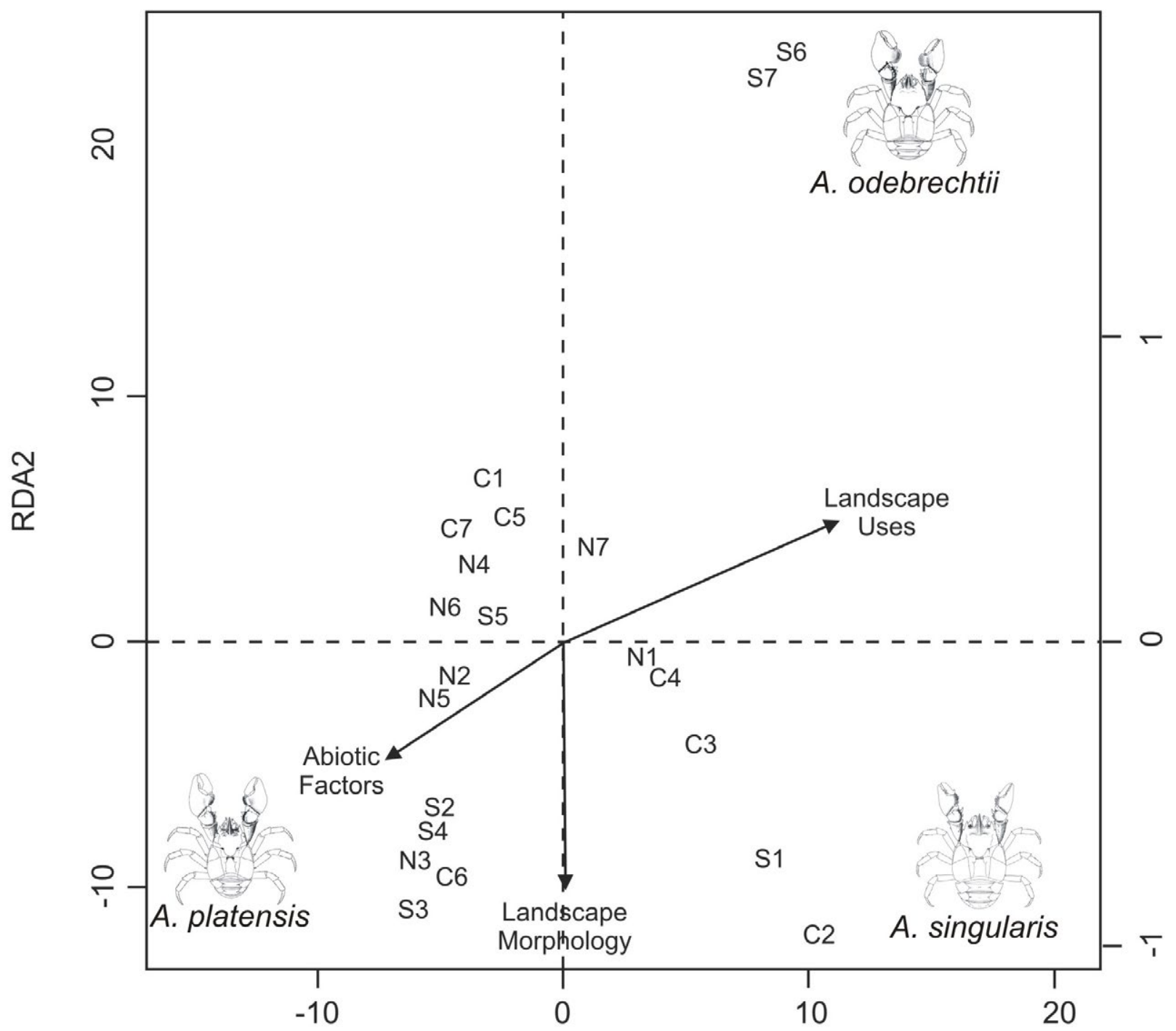

RDA1

Fig. 3. RDA between landscape uses, stream morphology, and abiotic factors that influence the distribution of Aegla in the study area, state of Rio Grande do Sul, southern Brazil. 
environments have low availability of dissolved oxygen in the water, which causes the disappearance of aquatic organisms (HEPP \& SANTOS, 2009). Although the study area was located in a predominantly agricultural zone, the release of untreated sewage potentiates the input of nutrients and organic matter, deteriorating the water quality of the streams studied. TREVISAN et al. (2009) observed A. singularis in streams near urban areas, suggesting that this species has some tolerance to higher concentration of nutrients. DALOSTO $\&$ SANTOS (2010) described that the A. longirostri has more oxygen-independent pattern, in contrast with described about Aegla in the literature (see BoND-BUCKUP \& BUCKUP, 1994).

Aegla odebrechtii was most influenced by different land uses, especially pasture and exposed agricultural soil. These particular uses are extremely impactful to aquatic river basin environments. Agriculture and exposed soils contribute to the supply of chemicals, heavy metals, and nutrients in the water (SENSOLO et al., 2012). In addition, agricultural activities promote the removal of riparian vegetation, causing instability in the banks of rivers and streams and increasing the sediment supply to these environments (HePP et al., 2016). We found that the occurrence of $A$. odebrechtii was associated with streams without vegetation.

Aegla platensis was more sensitive to the limnological characteristics of the streams. This demonstrates that the sensitivity of this crustacean to environmental variation occurs on a local scale. Aquatic invertebrates are sensitive to various environmental characteristics observed at different spatial scales (e.g. streams or drainage areas). For some crustaceans, the limnological characteristics of streams are key. Thus, the occurrence of $A$. platensis in streams with high total organic carbon concentrations suggests that this species has a higher environmental tolerance. TREVISAN et al. (2009) also observed this species in urban areas with low concentration of dissolved oxygen. In aquatic environments, high organic carbon concentrations reflect a significant decrease in the oxygen concentrations, since microrganisms consume this resource during their aerobic metabolism.

This study showed that the diversity of Aegla in the streams of northern region of Rio Grande do Sul is relatively low, since we found only 3 species. One reason for the low diversity could be elevated levels of human activity near the aquatic environments, which contributes to decreased water quality. Among the numerous environmental indicators studied, only average slope, nitrogen levels in water, exposed soil or agriculture, and use of the land for pastures were important factors in the occurence of these species. Moreover, the three species found showed an environmental plasticity to adapt to harsh environments. Finally, our results support the urgent need for conservation of these water resources as it directly influences the occurrence and distribution of aquatic species.

Acknowledgements. We would like to thank Rafael Chaves Loureiro, Giamarco Dariva and José Estevan, for help in field collections. We also thank Franciele Rosset for guidance in the construction of map. Finally, we thank Dra. Rozane Maria Restello and Dr. Sandro Santos for suggestions on early versions of this paper. LUH received financial support from Conselho Nacional de Desenvolvimento Científico e Tecnológico (process \#421632/2016-0) and research productivity grants (process \#305203/2017-7).

\section{REFERENCES}

Almerão, M. P.; Rudolph, E.; Souty-Grosset, C.; Crandall, K.; Buckup, L.; Amouret, J.; Verdi, A.; Santos, S. \& Araujo, P. B. 2015. The native South American crayfishes (Crustacea, Parastacidae): state of knowledge and conservation status. Aquatic Conservation: Marine and Freshwater Ecosystems 25:288-301.

Alvares, C. A.; Stape, J. L; Sentelhas, P. C; Gonçalves, J. L. M. \& SparoveK, G. 2013. Köppen's climate classification map for Brazil. Meteorologische Zeitschrift 22:711-728.

APHA. 1998. Standard methods for the examination of water and wastewater. 20ed. Washington, American Public Health Association. $541 \mathrm{p}$.

BERnARDI, S. \& BudKe, J. C. 2010. Estrutura da sinúsia epifítica e efeito de borda em uma área de transição entre Floresta Estacional Semidecídua e Floresta Ombrófila Mista. Floresta 40:81-92.

Bond-Buckup, G. \& Buckup, L. 1994. A família Aeglidae (Crustacea Decapoda Anomura). Arquivos de Zoologia do Estado de São Paulo 32:159-346.

Bu, H.; Meng, W.; Zhang, Y. \& Wan, J. 2014. Relationships between land use patterns and water quality in the Taizi River basin, China. Ecological Indicators 41:187-197.

Buckup, L. 2010. Parastacus pugnax. In: IUCN 2013. IUCN Red List of Threatened Species. Version 2013.2. Available at $<\mathrm{http}: / / \mathrm{www}$. iucnredlist.org >. Accessed on November 2013.

Christofoletti, A. 1980. Geomorfologia. São Paulo, Edgar Blucher. 188p.

Crivellaro, M. A.; Zimmermann, B. L.; Bartholomei-Santos, M. B.; PÉrez-Losada. M.; Bond-Buckup, G. \& SAnTos, S. 2018. Looks can be deceiving species delimitation reveals hidden diversity in the freshwater crab Aegla longirostri (Decapoda: Anomura). Zoological Journal of the Linnean Society 182:24-37.

Dalosto, M. \& Santos, S. 2011. Differences in oxygen consumption and diel activity as adaptations related to microhabitat in Neotropical freshwater decapods (Crustacea). Comparative Biochemistry and Physiology, Part A 160:461-466.

De Toni, K. R.; Nava, D.; Restello, R. M.; Decian, V.; Rovani, I. L. \& HePP, L. U. 2014. Integridade da paisagem e sua influência sobre a composição da comunidade de Chironomidae (Diptera) em riachos de pequena ordem. Ecología Austral 24:335-342.

Decian, V. S.; Zanin, E. M.; Henke-Oliveira, C.; Rosset-Quadros, F. \& FERRARI, C. 2009. Uso e ocupação da terra na região Alto Uruguai do Rio Grande do Sul e obtenção de banco de dados relacional de fragmentos de vegetação arbórea. Perspectiva 33:165-176.

Elosegi, A. \& Sabater, S. 2013. Effects of hydromorphological impacts on river ecosystem functioning: a review and suggestions for assessing ecological impacts. Hydrobiologia 712:129-143.

Ferreira, W. R.; Ligeiro, R.; Macedo, D. R.; Hughes, R. M.; Kaufmann, P. R.; Oliveira, L. G. \& CAllisto, M. 2014. Importance of environmental factors for the richness and distribution of benthic macroinvertebrates in tropical headwater streams. Freshwater Science 33:860-871.

Foley, J. A.; DeFries, R.; Asner, G. P.; Barford, C.; Bonan, G., Carpenter, S. R.; Chapin, F. S.; Coe, M. T.; Daily, G. C.; Gibbs, H. K.; Helkowski, J. H.; Holloway, T.; Howard, E. A.; Kucharik, C. J.; Monfreda, C.; Patz, J. A.; Prentice, I. C.; Ramankutty, N. \& Snyder, P. K. 2005. Global consequences of land use. Science 309:570-574.

Gonçalves, R. S.; Castiglioni, D. A. \& Bond-Buckup, G. 2006. Ecologia populacional de Aegla franciscana (Crustacea Decapoda Anomura) em São Francisco de Paula, RS, Brasil. Iheringia, Série Zoologia 76(1):109-114.

Hepp, L. U. \& Santos, S. 2009. Benthic communities of streams related to different land uses in a hydrographic basin in southern Brazil. Environmental Monitoring and Assessment. 156:305-318. 
Hepp, L. U.; Milesi, S. V.; Biasi, C. \& Restello, R. M. 2010. Effects agricultural and urban impacts on macroinvertebrates assemblages in streams (Rio Grande do Sul, Brazil). Revista Brasileira de Zoologia 27:106-113.

Hepr. L. U.; Urbim, F. M.; Tonello, G.; Loureiro, R.; Sausen, T.; Fornel, R. \& Restello, R. M. 2016. Influence of land-use on structural and functional macroinvertebrate composition communities associated on detritus in Subtropical Atlantic Forest streams. Acta Limnologica Brasiliensia 28:1-10.

Kang, J. H.; Lee, S. W.; Cho, K. H.; Ki, S. J.; Cha, S. M. \& Kiм, J. H. 2010. Linking land-use type and stream water quality using spatial data of fecal indicator bacteria and heavy metals in the Yeongsan river basin. Water Research 44:4143-4157.

Knysh, K. M.; Giberson, D. J. \& van den Heuvel, M. R. 2016. The influence of agricultural land-use on plant and macroinvertebrate communities in springs. Limnology and Oceanography 61:518-530.

Machado, P. J. O.; Zaidan, R. T.; Bernardino, J. L. \& Teofilo, S. V. 2009. Morfometria e Avaliação de Vulnerabilidade em Sub-bacias Hidrográficas no Município de Rio Pomba/MG. Fórum Ambiental da Alta Paulista 5:186-204.

Marchiori, A. B.; Bartholomei-Santos, M. L. \& Santos, S. 2014. Intraspecific variation in Aegla longirostri (Crustacea: Decapoda: Anomura) revealed by geometric morphometrics: evidence for ongoing speciation? Biological Journal of the Linnean Society 112:31-39.

Myers, N.; Mittermeier, R. A.; Mittermeier, C. G.; Fonseca, G. A. B. \& KenT, J. 2000. Biodiversity hotspots for conservation priorities. Nature 403:853-858.

Ngoye, E. \& Machiwa, J. F. 2004. The influence of land-use patterns in the Ruvu river watershed on water quality in the river system. Physics and Chemistry of the Earth, Parts A/B/C 29:1161-1166.

Oksanen, J.; Blanchet, F. G.; Friendly, M.; Kindt, R.; Legendre, P.; McGlinn, D.; Minchin, P. R.; O’Hara, R. B.; Simpson, G. L.; Solymons, P.; Stevens, M. H. H.; Szoecs, E. \& Wagner, H. 2010. Vegan: Community Ecology package. $R$ package version 1.17-0.

Oliveira, P. C. A.; Rodrigues, G. S. S. C. \& Rodrigues, S. C. 2008. Fragilidade ambiental e uso do solo da bacia hidrográfica do Córrego Pindaíba, Uberlândia, MG, Brasil. Revista Ambi-Água 3(1):54-67.

Oliveira-Filho, A. T.; Budke, J. C.; JarenKow, J. A.; Eisenlohr, P. V. \& Neves, D. R. M. 2015. Delving into the variations in tree species composition and richness across South American subtropical Atlantic and Pampean forests. Journal of Plant Ecology 8(3):242-260.

Olszevski, N.; Fernandes-Filho, E. I.; Costa, L. M.; Schaefer, C. E. G. R.; SouzA, E.; SouZA, E. \& Costa, O. D. 2011. Morfologia e aspectos hidrológicos da bacia hidrográfica do rio Preto, divisa dos estados do Rio de Janeiro e de Minas Gerais. Revista Árvore 35(3):485-492.

PofF, N. L.; Allan, J. D.; Bain, M. B.; KarR, J. R. \& PrestegaARD, K. L. 1997. The natural flow regime. BioScience 47:759-784.
R Core Team. 2013. R: A Language and Environment for Statistical Computing. R Foundation for Statistical Computing. Available at $<$ http://www.r-project.org $>$.

Ribeiro, J. C. \& Salomão, F. X. T. 2003. Abordagem morfopedológica aplicada ao diagnóstico e prevenção de processos erosivos na bacia hidrográfica do alto rio da casca, MT. Geociências 22(1):83-95.

Ribeiro, M. D.; Teresa, F. B. \& CASATti, L. 2016. Use of functional traits to assess changes in stream fish assemblages across a habitat gradient. Neotropical Ichthyology 14(1):e140185.

Santos, C. A. \& Sobreira, F. G. 2008. Análise morfométrica como subsídio ao zoneamento territorial: o caso das bacias do Córrego Carioca, Córrego do Bação e Ribeirão Carioca na região do Alto Rio das Velhas-MG. Revista da Escola de Minas 61(1):77-85.

Santos, S.; Bond-Buckup, G.; GonÇalves, A. S.; Bartholomei-Santos, M. L.; BUCKUP, L. \& JARA, C. G. 2017. Diversity and conservation status of Aegla spp. (Anomura, Aeglidae): an update. Nauplius 25:1-14.

Sensolo, D.; Hepr, L. U.; Decian, V. \& Restello, R. M. 2012. Influence of landscape on assemblages of Chironomidaein Neotropical streams. Annales de Limnologie - International Journal of Lomnology 48:391-400.

Souza, A. L. T.; Fonseca, D. G.; Libório, R. A.; \& TANaka, M. O. 2013. Influence of riparian vegetation and forest structure on the water quality of rural low-order streams in SE Brazil. Forest Ecology and Management 298:12-18.

Teresa F. B.; Casatti, L. \& Cianciaruso, M. V. 2015. Functional differentiation between fish assemblages from forested and deforested streams. Neotropical Ichthyology 13(2):361-370.

Theodoropoulos, C.; Aspridis, D. \& Iliopoulou-Georgudaki, J. 2015. The influence of land use on freshwater macroinvertebrates in a regulated and temporary Mediterranean river network. Hydrobiologia 751:201-213.

Trevisan, A.; Hepr, L. U. \& SAntos, S. 2009. Abundância e distribuição de Aeglidae (Crustacea: Anomura) em função do uso da terra na bacia hidrografica do Rio Jacutinga, Rio Grande do Sul, Brasil. Zoologia 26(3):419-426

Vörösmarty, C. J.; Mcintyre, P. B.; Gessner, M. O.; Dudgeon, D.; Prusevich, A.; Green, P.; Glidden, S.; Bunn, S. E.; Sullivan, C. A.; Liermann, C. R. \& Davies, P. M. 2010. Global threats to human water security and river biodiversity. Nature 467:555-561.

Woodward, G.; Gessner, M. O.; Giller, P. S.; Gulis, V.; Hladyz, S.; Lecerf, A.; Malmqvist, B.; McKie, B. G.; Tiegs, S. D.; Cariss, H.; Dobson, M.; Elosegi, A.; Ferreira, V.; Graça, M. A. S.; Fleituch, T.; Lacoursière, J. A.; Nistorescu, M.; Pozo, J.; Risnoveanu, G.; Schindler, M.; Vadineanu, A.; Vought, L. B.-M. \& Chauvet, E. 2012. Continental-scale effects of nutrient pollution on stream ecosystem functioning. Science 336:1438-1440.

Appendix 1. Parameters used for the morphometric evaluation of river basins in accordance with the methodology presented by CHRISTOFOLETTI (1980).

\begin{tabular}{|c|c|}
\hline Rated parameter & Description \\
\hline Size of the basin & Calculated in ha (hectare) and refers to the total area measure of the basin \\
\hline Perimeter of drainage areas & $\begin{array}{l}\text { Total length of the perimeter delimited by the topographic divisors of the drainage areas that are the subject of } \\
\text { biological data collection }\end{array}$ \\
\hline Density of drainage (Dd) & Drainage capacity exerted by the main channel and tributaries of the river basin \\
\hline Circularity Index (Ci) & Check the shape of basin, establishing whether it is more circular or elongated \\
\hline Average Declivity (Ad) & $\begin{array}{l}\text { It influences the flow velocity of the flow allowing a greater or lesser use of the force generated by gravity, being } \\
\text { related to the erosive capacity of the Hydrographic Basin }\end{array}$ \\
\hline Coefficient of roughness $(\mathrm{Cr})$ & $\begin{array}{l}\text { Environmental parameter related to probability to water erosion, pointing out possible uses of the soil in } \\
\text { accordance with its characteristics }\end{array}$ \\
\hline Gradient of the main river $(\mathrm{G})$ & It detects alterations \\
\hline
\end{tabular}

